P-ISSN: 2774-4574; E-ISSN: 2774-4574 TRILOGI, 2(1), Januari-April 2021 (22-34) @2021 Lembaga Penerbitan, Penelitian, dan Pengabdian kepada Masyarakat (LP3M) Universitas Nurul Jadid Paiton Probolinggo

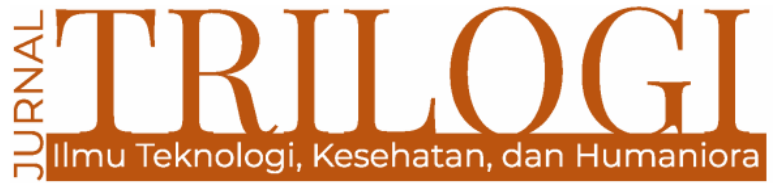

\title{
PENGEMBANGAN POTENSI UNIT USAHA PONDOK PESANTREN NURUL JADID MELALUI EKOPROTEKSI
}

\author{
Alvan Fathony \\ Universitas Nurul Jadid, Probolinggo, Jawa Timur \\ emailauthor@institution.ac.id \\ Rokaiyah \\ Universitas Nurul Jadid, Probolinggo, Jawa Timur \\ emailauthor@institution.ac.id \\ Sofiyatul Mukarromah \\ Universitas Nurul Jadid, Probolinggo, Jawa Timur \\ emailauthor@institution.ac.id
}

\begin{abstract}
Islamic Boarding School is one of the institutions that has a lot of potential, including economic potential. To increase this potential is a challenge for pesantren in order to prosper the economy of the pesantren itself and the wider community. The economic independence of Nurul Jadid Islamic boarding school cannot be seen from the building which is currently developing rapidly. The spirit of independence of the santri that is formed can be a potential for the pesantren to improve the economic stability of the pesantren. One of the efforts to make Nurul Jadid Islamic boarding school independent is through a business unit. Where a well-organized business will provide output with good income. In economic management, Islamic boarding schools need an instrument as a guarantee for smoothness and convenience, as well as business protection that has been actively played by the pesantren community. The instrument that is considered appropriate is ecoprotection. Ecoprotection is protection in order to make Islamic boarding schools independent and create or break away from dependence and build and maintain its existence, through an economy that is actualized in the function of economic management, economic independence is needed so that Islamic boarding schools can develop and be sustainable as part of their contribution to the nation's moral education. There are 3 pillars of economic business unit development, including creating a climate that allows the potential of the pesantren community to develop, strengthening the potential of the pesantren community and protecting its economic business units. The management process of the economic business unit at the Islamic boarding school and its development has a very positive impact on achieving mutual prosperity. The positive impact can be seen in several ways; a) the creation of a pattern of community cadres (santri and society) that are independent in the economic field, b) the formation of independent Islamic boarding schools in the economic sector, c) making pesantren as partners for the government, and d) being able to raise the economy of the people (the economy of the community around the pesantren and society as well).
\end{abstract}

Keywords: Islamic boarding school; Management; Ecoprotection 


\begin{abstract}
Abstrak
Pondok Pesantren merupakan salah satu lembaga yang memiliki banyak potensi, termasuk potensi ekonomi. Untuk meningkatkan potensi tersebut merupakan tantangan bagi pesantren agar dapat mensejahterakan perekonomian pesantren itu sendiri maupun masyarakat luas. Kemandirian ekonomi pesantren Nurul Jadid tidak bisa dilihat dari gedungnya yang saat ini sedang berkembang pesat. Jiwa kemandirian santri yang terbentuk dapat menjadi potensi bagi pesantren untuk meningkatkan stabilitas ekonomi pesantren. Salah satu upaya memandirikan pondok pesantren Nurul Jadid adalah melalui unit usaha. Dimana usaha yang terorganisir dengan baik akan memberikan output dengan income yang baik. Dalam pengelolaan ekonomi, pondok pesantren membutuhkan suatu instrumen sebagai penjaminan atas kelancaran dan kemudahan, serta perlindungan usaha yang telah diperankan secara aktif oleh masyarakat pesantren tersebut. Instrumen yang dipandang tepat adalah ekoproteksi. Ekoproteksi adalah perlindungan dalam rangka memandirikan ekonomi pesantren dan mewujudkan atau melepaskan diri dari ketergantungan serta membangun dan mempertahankan eksistensinya, melalui ekonomi yang diaktualisasikan dalam fungsi manajemen ekonomi, kemandirian ekonomi diperlukan agar pondok pesantren dapat berkembang dan berkelanjutan sebagai bagian dari sumbangsih dalam pendidikan moral bangsa. Ada 3 pilar pengembangan unit usaha ekonomi, diantaranya menciptakan iklim yang memungkinkan potensi masyarakat pesantren berkembang, memperkuat potensi yang dimiliki masyarakat pesantren dan melindungi unit usaha ekonominya. Proses manajemen unit usaha ekonomi di Pondok Pesantren serta pengembangannya memiliki dampak yang sangat positif untuk mencapai kesejahteraan bersama. Dampak positif tersebut secara nyata dapat dilihat pada beberapa hal; a) terciptanya pola kader umat (santri dan masyarakat) yang mandiri dalam bidang ekonomi, b) terbentuknya pesantren yang mandiri dalam bidang ekonomi, c) menjadikan pesantren sebagai patner pemerintah, dan d) mampu mengangkat ekonomi umat (ekonomi masyarakat sekitar pesantren maupun masyarakat secara luas).
\end{abstract}

Katakunci: Pondok Pesantren; Manajemen; Ekoproteksi

\section{Pendahuluan}

Pondok pesantren merupakan lembaga pendidikan tertua di Indonesia yang dimulai dan dibawa oleh wali songo untuk mengembangkan ilmu agama bagi umat islam. Ciri khas yang diambil dari lembaga pendidikan pondok pesantren yaitu kiyai sebagai pemilik pesantren dengan dibantu oleh ustadz dan ustadzah sebagai tenaga pendidik bagi santri untuk lebih memperdalam ilmu agama (Marlina 2014). Saat ini pesantren di Indonesia telah tersebar luas sampai kepelosok negeri, hal ini menciptakan tradisi tersendiri sesuai dimana tempat pondok pesantren itu berada. Namun tak sedikit dari itu dapat bertahan lama, karena kurangnya kualitas pendidikan, sarana dan prasana yang kurang memadai serta manajemen keuangan yang masih bergantung pada iuran santri. Pesantren harus lebih kreatif dalam mengembangkan potensi ekonomi untuk membantu manajemen keuangan pesantren serta bekal santri agar bisa mandiri dalam mengelola usaha (Anwarrosid 2020).
Adanya pesantren saat ini menjadi daya tarik tersendiri bagi masyarakat, baik kiai ataupun sistem pembelajarannya. Ini yang menjadikan pesantren tampil beda dengan lembaga pendidikan diluar pesantren. Pesantren saat ini tampaknya perlu di apresiasi lebih baik dari sebelumnya, karena di era globalisasi ini tampaknya pesantren mampu bersaing dengan dunia luar pesantren. Banyak pesantren yang berhenti beroperasi dikarenakan keterbatasan dana. Dana merupakan hal penting yang banyak diperbincangkan karena memang tidak mudah untuk mendapatkannya. Ada juga pesantren yang berhenti beroperasi akibat kurangnya antusias baik dari santri maupun dari masyarakat. Bisa jadi karena tidak ada peningkatan terhadap lembaga pendidikan atau kurang memadainya sarana dan prasarana pondok pesantren tersebut (S. N. Azizah 2016).

Seiring dengan berkembangnya zaman, Pondok Pesantren mengalami kemajuan. Saat ini Pesantren tidak hanya terfokus pada lembaga pendidikan saja, melainkan juga membangun usaha yang dapat membantu 
perekonomian pesantren. Bahkan, serikat bisnis pesantren telah terbentuk di Jawa Timur. Beberapa Pondok Pesantren telah bergabung di dalamnya. Ada Pondok Pesantren Zainul Hasan Genggong, Pondok Pesantren Tambak Beras Jombang, tak terkecuali Pondok Pesantren Nurul Jadid Paiton probolinggo, dan masih banyak lagi (Rahman 2019).

Pondok Pesantren mendirikan unit usaha tak lain dan tak bukan untuk memiliki tujuan tersendiri, tujuan yang mendasar biasanya untuk melatih santri agar mandiri dan mensejahterakan santri serta pengelola unit usaha itu sendiri. Jika warga pesantren hidup sejahtera, maka pesantren bisa dikatakan maju (Muslimin 2019). Untuk mensejahterakan pengelola usaha, biasanya pesantren menyediakan tempat tinggal, tunjangan, dan beberapa insentif lainnya. Hal ini dilakukan sebagai bentuk terima kasih kepada pengelola usaha karena sudah berpartisipasi dalam pengelolaan unit usaha pesantren (Yuliani, Y. 2019). Berkembangnya suatu usaha merupakan indikator penting bagi perkembangan usaha pesantren. Maka dari itu, nilai-nilai penting dalam suatu usaha diterapkan didalamnya demi menjaga kestabilan usaha pesantren. Akan tetapi, tidak menutup kemungkinan pengelola usaha pesantren akan pensiun atau tutup akibat beberapa faktor (Lugina 2018).

\section{Metode}

Pendekatan metode penelitian yang digunakan dalam penelitian ini adalah pendekatan kualitatif karena dalam penelitian ini menghasilkan kesimpulan berupa data yang mengagambarkan secara rinci, bukan data yang berupa angka-angka. Hal ini karena pendekatan kualitatif sebagai prosedur penelitian yang menghasilkan data deskriptif berupa kata-kata tertulis atau lisan dari orang-orang dan perilaku yang diamati.

Jenis penitian yang digunakan dalam penelitian ini adalah jenis penelitian kualitatif deskiptif. Dimana penelitian kualitatif itu sendiri adalah penelitian yang bermaksud untuk memahami fenomena tentang apa yang dialami oleh subjek penelitian misalnya perilaku, persepsi, motivasi, tindakan, dan lain secara holistic, dan dengan cara deskripsi dalam bentuk kata-kata dan bahasa.
Dalam penelitian kualitatif, data yang diambil adalah berupa kata-kata tertulis maupun lisan serta perilaku yang diamati dari objek penelitian data yang terkumpul harus mengambarkan dan melukiskan objek yang diteliti sesuai dengan keadaan yang sebenarnya.

Sesuai dengan permasalahan dan tujuan penelitian, peneliti berusaha menggambarkan bagaimana pengembangan yang dilakukan oleh pengelola unit usaha pondok pesantren Nurul Jadid melalui ekoproteksi. Maka jenis penelitian kualitatif yang membutuhkan pendekatan penelitian untuk mendeskripsikan data atau hasil penelitian.

\section{Hasil dan Pembahasan}

\section{Strategi Pengembangan Unit Usaha Pondok Pesantren}

Pesantren merupakan lembaga pendidikan yang diarahkan lebih kepada ilmu agama. Meningkatnya jumlah santri setiap tahun merupakan tantangan tersendiri bagi lembaga pendidikan umum dan madrasah. Dimana para santri yang sudah menyelesaikan pendidikannya harus berlomba-lomba untuk meneruskan ke bangku kuliah atau mencari pekerjaan. Hal ini dirasakan di era globalisasi ini dengan meningkatnya jumlah angka pengangguran. Fakta ini membuktikan bagaimana lembaga pendidikan pesantren harus lebih meningkatkan kualitas pendidikannya baik dari segi fasilitas, pembiayaan, tenaga kependidikan, maupun manajemen (Muhammad Khoirun Nasirin 2020).

Banyaknya pesantren yang terpaksa berhenti beroperasi membuktikan bahwa lemahnya pesantren dalam merespon perubahan zaman. Sebagian lainnya juga mampu bertahan ala kadarnya tanpa ada peningkatan yang signifikan, baik dalam hal layanan pendidikan maupun sarana dan prasarana yang kurang memadai, yang akan berdampak buruk pada mutu lulusan pesantren (Faishal Achmad 2012). Pondok pesantren yang digunakan hanya untuk menimba ilmu agama tidak akan bertahan lama dengan keadaan seperti saat ini. Beberapa aspek harus lebih diperhatikan termasuk dalam hal ekonomi dan manajemen. Dimulai dengan diadakannya pendidikan kewirausahaan kepada setiap santri dan 
praktek langsung dalam pesantren. Tenaga pendidik juga harus lebih kreatif dalam menemukan potensi yang ada agar dapat diolah dan mampu menghasilkan produk untuk menunjang ekonomi pesantren. Hal utama yang harus dilakukan adalah dengan memberikan kesadaran kepada santri akan pentingnya ilmu dalam berwirausaha agar dapat menjalankannya dengan sepenuh hati (Mughni 2018).

Pengelolaan sumber daya manusia di pesantren harus sejalan dengan fasillitas yang menunjang agar terjadi keselarasan antara pendidikan dengan ekonomi, maka pesantren harus mampu untuk mengelola dengan baik dan benar. Untuk merealisasikannya membutuhkan tenaga yang berkompeten agar dapat direalisasikan melalui pengorganisasian yang terstruktur sehingga dapat mencapai target yang diinginkan (Mukhidin 2019).

Model ekonomi pesantren yang berbasis syari'ah merupakan hal yang terpenting dalam bertransaksi khususnya umat islam, karena saat ini banyak ditemui transaksi yang bahkan sampai menjerumuskan dalam riba. Sehingga unit usaha yang akan dibangun pesantren nantinya sudah mempunyai landasan hukum syariah yang tentunya aman untuk dijalankan (Cholida, Wahyuni, and Widodo 2020).

Unit usaha merupakan salah satu cara pondok pesantren bertahan secara finansial untuk membantu keuangan pesantren dan tempat belajar santri berwirausaha. Dengan adanya unit usaha tersebut maka secara tidak langsung pondok pesantren tersebut telah menanamkan jiwa kewirausahaan dengan terbentuknya perekonomian melalui aktivitas yang dilakukan oleh santri yang mana hal tersebut dapat memberikan income (pemasukan) bagi pesantren. Dan dengan adanya unit usaha maka pondok pesantren telah mampu untuk membentuk jiwa pesantren seperti keikhlasan, kemandirian, dan kesederhanaan (Suharto and Fasa 2018).

\section{Tahapan analis manajemen unit usaha pesantren berbasis ekoproteski:}

a. Pondok Pesantren

Pondok Pesantren merupakan dua istilah yang menunjukkan satu pengertian. Pesantren menurut pengertian dasarnya adalah tempat belajar para santri, sedangkan pondok berarti rumah atau tempat tinggal sederhana terbuat dari bambu. Di samping itu, kata pondok berasal dari bahasa arabfunduq yang berarti asrama atau hotel. Di Jawa termasuk Sunda dan Madura umumnya digunakan istilah pondok dan pesantren, sedang di Aceh dikenal dengan Istilah dayah atau rangkang atau menuasa, sedangkan di Minangkabau disebut surau (Yunita Nur Laili F.M. 2020).

b. Perkembangan Pesantren di Era Modern

1) Perkembangan pola kepemimpinan dalam pesantren

Kenyataan bahwa nama dan pengaruh sebuah pesantren berkaitan erat dengan masing- masing pemimpinnya (Kyai) telah menunjukan, betapa kuatnya kecakapan dan pancaran kepribadian seorang pemimpi pesantren menentukan kedudukan dan tingkat suatu pesantren (Nurholisoh 2018). Sebagai contoh kecil dalam perjalanannya, kharismatik kyai sangat tampak pada saat permulaan pemndirian atau pembangunan pesantren, yakni dalam penggerakan masa masyarakat eksternal maupun masyarakat internal pesantren/santri untuk turut serta berperan dalam pembangunan tersebut, bahkan dalam pembiayaan sekalipun.

Dengan begitu sudah menjadi Hal umum bahwa pesantren merupakan sebuah institusi yang tak terpisahkan dari peran kyai. Kyai merupakan figure sentral, otoritatif, dan pusat seluruh kebijakan dan perubahan (Faishal Achmad 2012). Hal ini seperti yang telah diterangkan di atas bahwa ada dua faktor yakni pertama dalam pesantren merupakan tipikal kepemimpinan yang tersentralisasi pada individu yang bersandar pada kharisma serta hubungan yang bersifat paternalistik. Dalam perjalananya, pesantren menganut pola "serba mono" "mono manajemen, mono administrasi sehingga tidak ada delegasi kewenangan ke unit-unit kerja yang ada dalam organisasi (Mustaghfiri 2019).

Kedua, kepemilikan pesantren bersifat individual (keluarga) bukan komunal. Otoritas individu kyai sebagai pendiri sekaligus pengasuh pesantren sangat besar dan tidak bisa diganggu gugat. Dalam hal ini, faktor nasab (keturunan) juga sangat kuat, sehingga kyai mewariskan pesantren kepada anaknya (dalam istilah kerajaan seperti putra mahkota) yang telah dipercaya tanpa ada komponen pasantren yang berani melwan. 
Seiring berkembanganya zaman, setelah merebaknya pendirian sekolah-sekolah formal yang berbasis pesantren-yayasan sedikit banyak pesantren mengalami perkembangan pada aspek manajemen, organisasi, dan administrasi pengelolaan uang. Perkembangan ini dimulai dari perubahan gaya kepemimpinan dalam pesantren; dari kharismatik ke rasionalistik, dari otoriterpaternalistik ke diplomatik- partisipatif, atau dari laissez faire ke demokratik.

Sayangnya, perubahan tersebut tidak berkembang secara merata di semua pesantren. Secara umum pesantren masih menghadapi kendala serius menyangkut ketersediaan sumberdaya manusia professional dan penerapan manajemen yang umumnya masih konvensional, missalnya tiadanya pemisahan yang jelas antara yayasan, pimpinan, madrasah, guru, dan staf administrasi; tidak adanya transparasi pengelolaan sumber- sumber keuangan, belum terdistribusinya peran pengelolaan pendidikan, dan banyaknya penyelenggaraan administrasi yang tidak sesuai dengan standar, serta unit-unit kerja tidak berjalan sesuai aturan baku organisasi. Kyai masih merupakan figur sentral dan menentu kebijakan pendidikan pesantren. Rekruitment ustadz-ustadzah/guru, pengembangan akademik, reward system, bobot kerja juga tidak berdasarkan aturan yang baku. Penyelenggaraan pendidikan seringkali tanpa perencanaan (F. N. Azizah 2017).

2) Perkembangan pola pendidikan dalam pesantren

Permasalahan seputar pengembangan model pendidikan pondok pesantren dalam hubungannya dengan peningkatan kualitas sumberdaya manusia (human resources) merupakan isu actual dalam arus perbincangan kepesantrenan kontemporer. Maraknya perbincangan mengenai isu tersebut tidak bias dilepaskan dari realitas empiric keadaan pesantren yang dinilai kurang mampu mengoptimalisasi potensi yang dimilikinya. Setidaknya, ada dua potensi besar yang dimiliki pesantren yaitu potensi pendidikan dan pengembangan masyarakat (Sholihah Sari Rahayu, Aam Slamet Rusydiana 2020).

Terlihat jelas, ketidak optimalisasian pesantren dalam mengolah dua potensi besar tersebut yakni dari segi pendidian pesantren dapat dikatakan kalah dalam bersaing dalam menawarkan suatu model pendidikan kompettif yang mampu melahirkan output (santri) yang memiliki kompetensi penguasaan ilmu dan skill sekaligus sehingga menjadi bekal terjun ke dalam kehidupan social yang terus mengalami percepatan perubahan akibat modernisasi yang ditopang kecanggihan sains dan tekhnologi (Sulaiman et al. 2016). Kegagalan pesantren dalam melahirkan sumberdaya santri yang memiliki kecakapan dalam bidang ilmu- ilmu keIslaman dan penguasaan tekhnologi secara sinergis berimplikasi terhadap kemacetan potensi pesantren kapasitasnya sebagai salah satu agent of social change dalam berpartisipasi mendukung proses transformasi bangsa.

Seiring berjalannya waktu, dalam menghadapi problematika pendidikan pesantren dalam interaksinya dengan perubahan social akibat modernisasi ataupun globalisasi tersebut, dari kalangan internal pesantren sebenarnya telah mulai melakukan pembenahan. Salah satu bentuknya adalah pengembangan model pendidikan formal (sekolah), mulai tingkat SD sampai perguruan tinggi, dilingkungan pesantren dengan menawarkan perpaduan kurikulum keagamaan dan umum serta perangkat ketrampilan teknologis yang dirancangbangun secara sistematik-integralistik. Tawaran berbagai model pendidikan mulai dari SD unggulan, Madrasah Aliyah Program Khusus (MAPK), SLTP dan SMU Plus yang dikembangkan pesantren pun cukup kompetitif dan menarik minat masyarakat luas. Sebab, ada semacam jaminan keunggulan output yang siap bersaing dalam berbagai sector dalam kehidupan sosial.

Adapula sebagian pesantren yang memperbaharui sistem pendidikannya dengan menciptakan model pendidikan modern yang tidak lagi terpaku pada sistem pengajaran klasik (wetonan, bandongan) dan materi kitab-kitab kuning. Tetapi semua sistem pendidikan mulai dari teknik pengajaran pengajaran, materi pelajaran, sarana dan prasarana, didesain berdasarkan sistem pendidikan modern (Renny and Budi 2018).

\section{Langkah pesantren dalam mempersiapkan wiraswasta di pesantren}

a. Adanya komitmen dalam mengambil suatu kebijakan 
Langkah awal sebelum membentuk unit usaha adalah adanya komitmen dari pihak pimpinan, yang mana hal tersebut diharapkan dapat menjadikan awal adanya kebijakan dalam pengambilan keputusan pada ruang lingkup lembaga. Pimpinan pesantren harus dapat mengalikan bentuk kepemimpinannya dari tradisional ke modern agar sejalan dengan era globalisasi seperti saat ini (Prayitno 2016).

b. Harus mampu dalam mempersiapkan sumber daya manusia

Sumber daya manusia merupakan hal terpenting karena merekalah nantinya yang akan menjalankan unit usaha tersebut. Disini pesantren harus mempersiapkan sumber daya manusia yang amanah dan terampil, maka dari sini kita dapat mencapai tujuan dari dibentuknya organisasi tersebut (Nurholisoh 2018).

\section{c. Membentuk unit usaha}

Unit usaha tersebut akan dijalankan dalam lingkungan pesantren, yang artinya pesantren harus mampu untuk menciptakan unit usaha yang sesuai dengan lingkungannya, dimana unit usaha tersebut bukan milik pribadi melainkan milik lembaga. Unit usaha dalam pesantren bisa dalam bentuk seperti koperasi, kantin dan sebagainya (Zaenudin 2018).

\section{Pondok Pesantren Nurul Jadid}

Awal berdirinya pondok Nurul Jadid adalah berkat kedatangan KH. Zaini Mun'in pada tanggal 10 Muharram 1948, ke desa Karangaanyar. Pada awalnya KH. Zaini Mun'in tidak bermaksud mendidrikan pondok pesantren, tapi ia mengisolir diri dari keserakahan dan kekejaman kolonel belanda serta ia mau melanjutkan perjalanan ke pedalaman Yogyakarta untuk bergabung bersama teman-temannya. Sebenarnya, citacita $\mathrm{KH}$. Zaini Mu'in untuk menyiarkan agama Islam lewat Departemen Agama (Depag). Namun, niat itu menemui kegagalan, sebab sejak ia menetap di desa Karanganyar beliau mendapat titipan (amanah) Allah berupa dua orang santri yang datang kepada $\mathrm{KH}$. Zaini Mun'in untuk belajar ilmu agama. Kedua orang tersebut bernama Syafi'uddin yang berasal dari Gondosuli, Kotaanyar Probolinggo dan Saifuddin dari Sidodadi Kecamatan Paiton, Probolinggo.

Kedatangan kedua santri tersebut oleh beliau dianggap sebuah amanah dari Allah SWT. yang tidak boleh diabaikan. Dan mulai saat itulah, ia mulai menetap bersama kedua santrinya. Namun tidak beberapa lama, KH. Zaini Mun'in ditangkap oleh belanda dan dipenjarakan di LP. Probolinggo, karena waktu itu ia termasuk orang yang dicari- cari oleh belanda semenjak dari pulau Madura. Belanda menganggap $\mathrm{KH}$. Zaini Mun'in seoarang yang berbahaya, karena menurut belanda, ia mampu mempengaruhi dan mengerakkan rakyat untuk melawan penjajah belanda. Setelah sekitar tiga bulan dalam penjara, kemudian ia dipulangkan lagi ke Karanganyar untuk mengasuh santri-santrinya.

Sejak kepulangan dari penjara itulah, $\mathrm{KH}$. Zaini Mun'in membimbing para santrisantrinya yang mulai berdatangan dari berbagai daerah. Mulai dari Madura, Bondowoso, Situbondo dan Probolinggo. Mula-mula santri berdatangan sekitar 30 orang, namun seiring berjalannnya waktu pondok pesantren Nurul Jadid mengalami santri yang sangat pesat hingga mencapai ribuan santri dari berbagai penjuru tanah air, bahkan dari luar negeri (Sigapura dan Malaysia). Sedangkan nama "Nurul Jadid" adalah merupakan sebuah usulan dari guru kiai Zaini Mun'in yang bernama KH. Baqir. Ia mengharap kepada kiai Zaini Mun'in untuk memberi nama pesantrennya dengan nama Nurul Jadid (Cahaya Baru). Namun pada saat ini pula, kiai Zaini Mun'in menerima surat dari Habib Abdullah bin Faqih yang memohon agar pesantrennya diberi nama "Nurul Hadis". Dari dua nama itu kemudian nama Nurul Jadid yang diambil, yang berarti cahaya baru (Ishaq 2018).

Keberadaan Pondok Pesantren Nurul Jadid tidak lepas dari konstruksi kemasyarakatan yang menceritakan suatu transendensi atas sejarah perjalan historitas sosial. Hal yang menjadi titik penting adalah eksistensi pesantren sebagai salah satu pemicu terwujudnya kohesi sosial. Sehingga pesantren hadir dengan semangat kesederhanaan, kekeluargaan dan kepedulian sosial. Berdirinya Pondok Pesantren Nurul Jadid memang bukan sekedar pemenuhan kebutuhan keilmuan, melainkan juga karena menjaga terhadap tradisi budaya, penyebaran etika dan moralitas keagamaan. Tak heran, pada periode awal santri lebih diarahkan agar lebih memahami bentuk aplikasi dari teori ilmu-ilmu keagamaan yang mereka pelajari dalam kitab-kitab kuning. Sehingga nantinya, para santri bisa mengamalkan teori ilmu-ilmu 
keagamaan secara tepat dan benar ketika mereka sudah terjun di masyarakat.

Hal itu bisa dilihat misalnya dalam bidang ekonomi, khususnya pertanian. Sektor pertanian dijadikan prioritas. Hal ini tidak lepas dari pendapat $\mathrm{KH}$. Zaini, jika bidang perekonomian suatu masyarakat lemah, maka sering kali itu menjadi pemicu tumbuh berkembangnya perilaku amoral dan kufur. Pendapat itu, diutarakan $\mathrm{KH}$. Zaini setelah melakukan analisa terhadap situasi dan kondisi perekonomian masyarakat yang amat rendah.

\section{Unit Usaha Pondok Pesantren Nurul Jadid}

Pondok pesantren Nurul Jadid menyiapkan dan membekali santrinya tidak saja dengan ilmu-ilmu agama saja, tetapi juga ketrampilan yang berguna bagi pengembangan masyarakat hal ini untuk menepis aggapan bahwa santri agak kelak, apaila kembali kemasayarakat siap mempelopori bidangbidang pembangunan lainya. Adapun ketrampilan yang diberikan meliputi; pelatihan menejemen koprasi, jahit menjahit: pelatihan (santri wanita), pertukaran, perbengkelan, mengukir, menejemen pertanian dan kewirausahaan. Selain itu, Sebagai agen pembangunan, pesantren tak hanya asik dengan dirinya sediri. Sebagai komunitas yang menyatu kepada masyarakat, tak jarang mereka tampil ke depan untuk mempelopori berbagai bentuk kegiatan pemberdayaan masyarakat sekitarnya. Sebagaimana pondok pesantren Al Ihya Ulumaddin sebagai lembaga pendidikan, pesantren ini tidak hanya peduli terhadap masalah agama saja, tetapi juga masalahmasalah kemasyarakatan.

Adapun bentuk kegiatan yang dilakukan oleh pondok pesantren dibidang ekonomi meliputi:

a. Kopontren Nurul Jadid sebagai pusat pengembangan perekonomian pesantren yang menyediakan kebutuhan sehari- hari santri.

b. Simpan pinjam BMT Tanjung

c. Mini Market NJ Mart

d. Unit perawatan Azzainiyah

e. Pustaka nurja

f. Enje enterprise

g. NJ Print

\section{Manajemen Pondok Pesantren}

Manajemen dalam pondok pesantren merupakan suatu proses untuk meningkatkan aset dan kemampuan pondok pesantren dalam bidang ekonomi untuk menuju keswadayaan dan kemandirian. Serta dengan menggunakan otoritas kebebasannya dalam memberdayakan aset serta kemampuan yang dimiliki. Sebagai penanggung jawaab umum atau top leader maka Kyai yang mempunyai wewenang agar guru-guru atau ustadz dan staf lain bekerja secara optimal dengan mendayagunakan sarana/prasarana yang dimiliki serta potensi masyarakat demi mendukung tercapaianya tujuan pesantren (Sungkawaningrum 2013).

Manajemen pesantren pada hakikatnya merupakan salah satu strategi dalam pembaharuan pesantren dalam bidang ekonomi yaitu sebagai suatu kegiatan yang dimaksudkan untuk memampukan dan memandirikan masyarakat pesantren. Dalam hal ini yaitu untuk meningkatkan kemampuan masyarakat pesantren melalui keterlibatan pada berbagai program pembangunan pesantren tersebut terutama dalam pengelolaan ekonomi serta memberikan kewenangan kepada masyarakat pesantren secara proporsional dalam pengambilan keputusan.

Manajemen seperti yang kita ketahui merupakan alat yang kuat serta sebagai pondasi dalam pembangunan lembagalembaga di Indonesia. Manajemen merupakan kunci untuk berjalannya suatu kegiatan, suatu usaha, suatu pemberdayaan dalam suatu organisasi dalam masyarakat secara luas, dalam hal ini secara khusus dalam lembaga pesantren secara ekonomi, yaitu pondok pesantren dalam usaha meningkatkan dan memperbaiki pesantren tersebut dalam bidang ekonomi sebagai salah satu penopang eksistensi pesantren (Rahman 2019).

Ada beberapa alasan mengapa pesantren memerlukan manajemen yang kuat dalam bidang ekonomi:

a. Penduduk Indonesia mayoritas beragama Islam dan pondok pesantren merupakan salah satu media yang paling dekat dengan masyarakat serta tumbuh dan berkembang sesuai dengan karakteristik masyarakat Indonesia yang beragama tersebut.

b. Kekuatan nilai-nilai pesantren yang berbasis ilahiah dan insaniah menjadi kekuatan yang menuju pada perubahan sosial. Sebagaimana dikatakan oleh Max Weber bahwa nilai-nilai agama yaitu 
ilahiah dan insaniah yang termasuk di dalamnya merupakan salah satu tranformasi sosial yang dapat dipandang sebagai dasar pembentukan rasionalisasi kehidupan yang memberi basis pada perkembangan ekonom.

c. Kondisis sosial ekonomi pondok pesantren yang masih dalam tahap perkembangan dengan kendala yang begitu banyak. Kesenjangan dan ketimpanganketimpangan sumber daya manusia serta etos kerja dan mindset masyarakat pesantren yang masih banyak harus dibenahi. Sehingga dalam rangka menjalanankan usaha ekonomi dalam pesantren tersebut sangat membutuhkan manajemen yang kuat, yang bagus dan tertata dan diupayakan dapat meningkatkan kemampuan pesantren untuk menganalisa kondisi dan potensi serta masalah- masalah yang perlu diatasi. Selain itu, ketidak berdayaan (dispowerment) inilah yang menyebabkan pesantren menjadi termarjinalkan. Sehingga tidak sepenuhnya bisa dipersalahkan jika selama ini banyak beredar gosip bahwa pesantren hanya menjadi wadah sumbangan dari masyarakat atau pemerintah. Oleh karena itu, diperlukan peran dari masyarakat pesantren bahkan dari Kiyai yang notabene adalah figur sentral dalam pesantren untuk mengambil keputusan, sehingga tujuan dari kegiatan unit usaha pesantren tersebut dapat tercapai (Januari 2018).

Dalam hal ini untuk membentuk individu dan masyarakat serta lembaga pesantren tersebut menjadi mandiri dalam bidang ekonomi yang sebagai salah satu penopang dari kemandirian sistem- sistem lain yang diterapkan dalam pondok pesantren. Kemandirian tersebut terdiri dari kemandirian berpikir, bertindak dan mengendalikan apa yang mereka lakukan sebagai strategi. Yaitu yang ditandai dengan kemampuan untuk memikirkan, memutuskan serta bertindak untuk menghasilkan sesuatu yang dipandang tepat demi pemecahan masalah yang dihadapi dengan didukung sumber daya manusia maupun sumber daya lain yang bersifat fisikmateriil. Sehingga diharapkan masyarakat pesantren mampu meningkatkan taraf ekonomi, serta mengoptimalkan sumber daya setempat baik itu sumber daya alam maupun sumber daya manusia (Suharto and Fasa 2018).

\section{Pengelolahan Usaha Pesantren}

Sebagaimana diketahui, kegagalan perekonomian pondok pesantren ialah dikarenakan adanya kebijakan pemerintah mengenai sistem ekonomi konglomerasi. Dalam kenyataanya, sistem ekonomi konglomerasi tersebut hanya menguntungkan satu pihak saja. Yaitu kelompok yang telah memiliki kemampuan dan akses ekonomi. Sementara itu, pondok pesantren adalah salah satu lembaga yang masih dalam kategori lemah dalam akses ekonomi. Akhinya tidak dapat mempertahankan kegiatan ekonominya secara mandiri adalah sebagai konsekuensi logisnya (Mughni 2018).

Oleh sebab itu, tidak ada jalan lain, pesantren harus melakukan manjemen yang rapi, tertata, dan kuat sebagai pondasi dalam tegaknya ekonomi pesantren. Manajemen usaha ekonomi pesantren mempunyai beberapa tujuan, dimana tujuan adalah sebuah konsekuensi logis dari hasil manajerial tersebut yang telah dilakukan oleh masyarakat pesantren secara terus menerus, berkelanjutan dan bertahap Sebagaimana diketahui aktivitas manajemen dalam pesantren mencakup spectrum yang cukup luas (Muttaqin 2016), sebab dimulai dari bagaimana menentukan arah organisasi di masa depan, menciptakan kegiatan-kegiatan organisasi, mendorong terbinanya kerja sama antara sesama anggota organisasi, yakni dalam hal ini memberdayakan santri sebagai anggota organisasinya, untuk mencapai tujuan, sehingga peranan manajemen mempunyai posisi yang sangat strategis, yaitu diantaranya:

a. Manajemen SDM Sebagai pendorong dan penguat ekonomi santri.

Sebagaimana diketahui, masalah SDM bukanlah masalah yang dialami pesantren saja, namun masalah tersebut merupaka masalah nasional bangsa Indonesia. Bahkan, yang lebih mengejutkan lagi sekitar kurang lebih dari 38,5 juta jumlah SDM yang lemah dalam masa pengangguran di Indonesia adalah komunitas alumni pesantren. Hal tersebut dikarenakan lemahnya skill individual-kolektif yang dimiliki alumni pesantren. Oleh karena itu, lewat pendirian unit usaha ekonomi pesantren yang didukung dengan manajemen yang kuat, dapat meningkatkan skill yang harus dimiliki oleh masyarakat pesantren agar dapat memenuhi serta dapat terjun dalam sektor riil dalam 
dunia perekonomian nanti. Selain itu, akan berdampak posistif bagi pesantren. Dengan SDM ekonomi yang memadai dapat menjadikan kegiatan pesantren yang berbasis ekonomi dapat terarah dan berkualitas. Sehingga menuai hasil yang dapat mensejahterakan masyarakat pesantren.

b. Manajemen Kelembagaan.

Kelembagaan merupakan salah satu hal yang urgen membutuhkan manajemen secara total. Selain meningkatkan kualitas kelembagaan pesantren, manajemen juga berdampak positif bagi kemampuan lembaga untuk menjangkau, menggunakan dan mempengaruhi pranata-pranata masyarakat sebagai pendukung kegiatan ekonomi berbasis pesantren tersebut. Tentunya, dalam kelembagaan tersebut harus disusun atau dalam kategori Integrted Structural yaitu lembaga dimana setiap unit dalam setiap bidang ada spesfikasi job description. Namun dalam kenyataanya kelmbagaan pondok pesantren masih berbentuk Integrated NonStructural.

c. Manajemen Inovasi dan Net-Working.

Selain sumber daya ekonomi pesantren, inovasi dan net-working adalah salah satu hal yang harus dimiliki karena dengan memiliki inovasi serta net- working akan lebih mudah membuka pasar. Karena fakta membuktikan bahwa problem yang paling mendasar adalah ketidak mampuan pesantren dalam melakukan terobosan keluar dalam hal ini mencari jaringan yang seluas mungkin. Baik antar pesantren mapun masyarakat bahkan institusi sosial dan institusi pemerintahan. Hal tersebut sangat menghambat perkembangan pesantren dalam bidang ekonomi.

d. Manajemen Potensi Ekonomi Lokal

Ekonomi lokal yang dimiliki pesantren dalam hal ini yang potensial merupakan salah satu subparameter dalam penilaian unit usaha ekonomi pesantren, apakah sudah dimanej dengan baik atau hanya selintas lalu, yakni asal berjalan,. Karena dalam kegiatan pengolahan unit usaha pesantren, mencakup tiga kategori yaitu, pertumbuhan ekonomi, pemerataan ekonomi dan pemberdayaan ekonomi lokal. Dari ketiga aspek tersebutlah yang menjadi salah satu kunci penilaian sejauh mana manajemen unit usaha ekonomi, terutama dalam memajukan geliat ekonomi tersebut.

e. Manajemen dalam Pemberadayaan Ekonomi Umat.
Pemberdayaan ekonomi umat merupakan salah satu pemberdayaan ekonomi yang bergerak ke arah ekonomi yang berbasis kerakyatan.Diantaranya adalah dengan memberdayakan usaha kecil masyarakat yang baru tumbuh maupun yang tengah berkembang. Pemberdayaan tersebut merupakan konsekuensi logis kegiatan unit usaha ekonomi pesantren. Pemberdayaan tersebut dapat dikatakan sebagai sasaran terakhir dari tujuan didirikannya unit usaha ekonomi ekonomi pondok pesantren yakni selain kemandirian pesantren juga mengangkat ekonomi umat (Marwini 2018).

Selain mempunyai posisi yang strategis dalam pesantren, sebuah pemberdayaan yang didukung adanya manajemen yang baik dalam pesantren juga mempunyai beberapa fungsi mendasar yang akan menjadi daya dukung serta pondasi yang kokoh bagi berjalannya kegiatan unit usaha pesantren. secara umum, fungsi-fungsi manajemen mencakup perencanaan, pengorganisasian, penggerakan, pengawasan. Dalam aplikasinya, fungsi-fungsi manajemen tersebut dijalankan untuk mengelola berbagai bidang tugas dalam pesantren yaitu mencakup aspek kurikulum, atau pengajaran, kesantrian, keuangan, sarana dan prasarana, material, hubungan dengan masyarakat (Fathoni and Rohim 2019). Dalam begitu, disadari benar betapa pentingnya peranan sumber daya (resources) yang dimiliki organisasi, baik sumber daya manusia (human resources) maupun sumber daya material. Karena pemanfaatan kedua sumber daya tersebut oleh manajer dalam suatu organisasi secara efektif dan efesien akan mengoptimalkan pencapaian tujuan organisasi. Pemanfaatan sumber daya organisasi tersebut dimulai dari melakukan perencanaan yang tepat, pengorganisasian yang mantap, penyusunan staf yang tepat dan profesional, pengarahan dan pengawasan yang terkendali dengan baik akan menjamin berfungsinya proses manajerial.

Dalam aplikasinya di pesantren fungsifungsi manajemen tidak jauh berbeda dari fungsi-fungsi lembaga pada umumnya yakni meliputi: Perencanaan, Organizing, Actuating dan Controling.

\section{Model Pengelolaan Unit Usaha Ekonomi berbasis Ekoproteksi}

a. Pengertian Ekoproteksi 
Ekoproteksi adalah penggabungan dua kata yaitu Ekonomi dan Proteksi dimana dalam kamus Ilmiah Popular, Eko adalah ekonomi dan Proteksi adalah perlindungan. Dalam pengertian yang lebih luas, proteksi merupakan suatu strategi perlindungan terhadap kegiatan ekonomi, perdagangan, atau sebuah industri. Pengertian ekonomi adalah segala usaha dan kegiatan manusia untuk mensejahterakan hidupnya. Proteksi adalah perlindungan dalam ruang lingkup tidak terlalu luas. Proteksi merupakan kiat cara perlindungan terhadap kegiatan ekonomi atau perdagangan (Mustaghfiri 2019).

Ekoproteksi merupakan perlindungan dalam rangka menjadikan ekonomi mandiri dan melepaskan diri dari ketergantungan. Serta membangun, mengembangkan, juga mempertahan kan keeksisannya, melalui ekonomi yang diaktualkan dalam fungsi manajemen ekonomi (Supeno 2019). Kemandirian ekonomi sangat diperlukan agar pesantren bisa terus berkembang secara berkelanjutan, sebagai bagian dari partisipasi dalam memajukan pendidikan moral bangsa. Dengan kata lain, ekoproteksi adalah suatu kiat cara atau strategi yang mencerminkan peran wujud suatu lembaga pendidikan yang menggunakan sistem button up untuk mewujudkan serta merealisasikan cita-cita pondok pesantren dalam rangka memandirikan ekonominya disertai dengan hak, kewajiban, dan juga tanggung jawab. Jadi, ekoproteksi dalam pondok pesantren merupakan suatu tanggung jawab yang harus juga wajib dijalankan juga dikelola oleh lembaga pesantren itu sendiri, serta masyarakat yang bermukim dalam lingkungan internal pesantren yang memiliki tanggung jawab dalam melindungi usaha pondok pesantren yang akan atau bahkan sedang berjalan.

Ekoproteksi dalam arti sempit merupakan sebuah sistem yang fokus beracuan pada pemanfaatan sumber daya intern (dalam lingkup lingkungan pesantren) dan kemandirian untuk mencapai ketahanan ekonomi yang berujung fokus pada eksistensi pondok pesantren itu sendiri, juga berfungsi sebagai suatu bentuk dalam melindungi usaha atau perekonomian yang tengah dirumuskan, direncanakan atau bahkan sedang berjalan .

b. Instrument Ekoproteksi dalam Pesantren.

Dalam pondok pesantren, ekoproteksi diperankan oleh:

\section{Kiyai-Ulama'}

Kiyai-Ulama' merupakan sosok figur paling utama dalam pondok pesantren. Kiyai-Ulama' adalah seorang pemimpin yang sangat bekharisma, taat beribadah kepada Allah, berpengalaman, berilmu, serta berwawasa luas (Gufronul 2020). Oleh sebab itu, KiyaiUlama selain memberikan pelajaran agama dan sebagai pemimpin spiritual juga menjadi dokter "Psikiomatis" bagi santri khususnya dan masyarakat pada umumnya. Sehingga ada kepercayaan tersendiri dari santri dan seluruh masyarakat internal pesantren maupun eksternal pesantren bahwa seorang Kiyai-Ulama adalah pewaris nabi yang telah disebutkan dalam hadist (Muhammad Anwar Fathoni 2019). Yang dalan kondisi tersebut, menunjukkan awal terbangunnya potensi ekonomi yang baik.

\section{Peran Pendidik dan Pendidikan}

Melalui pendidik dan pendidikan, maka pondok pesantren akan mampu dalam mengelola materi yang ada untuk membangun ekonomi pondok pesantren melalui ajaran nilai-nilai yang diberikan. Lewat peran pendidik dan pendidikan tersebut, akan mampu melindungi pemberdayaan ekonomi pondok pesantren (Laksono and Rohmah 2019).

\section{Peran Lembaga}

Lembaga merupakan suatu lingkup yang besar dalam pondok pesantren. Dimana lembaga pesantren terdiri dari keluarga ndalem (keluarga pesantren baik Kiyai maupun ustadz yang telah lama berdomisili dan ada hubungan darah dengan Kiyai), maupun jajaran kepengurusan baik kepengurusan pondok pesantren maupun kepengurusan secara khusus (dalam bidangbidang tertentu) (Rimbawan 2012).

Peran lembaga sebagai bagian lingkup besar dalam pesantren akan mampu berperan sebagai wadah konsultasi santri juga pengawas yang bertujuan mempertahankan dan melindungi usaha yang tengah diberdayakan dan dikembangkan oleh pondok pesantren.

\section{Peran Pemerintah}

Pemerintah, mempunyai peran keterlibatan dalam melindungi juga mendukung keberhasilan pemberdayaan 
ekonomi pondok pesantren. Peran pemerintah merupakan upaya menfasilitasi dan mendukung pengembangan ekonomi. Sistem ekoproteksi menerapkan konsep buttom-up (pesantren) dan up to down (dukungan dan perlindungan pemerintah) dapat berhasil sehingga pondok pesantren mampu memberdayakan ekonomi ummat atau masyarakat (Musa 2017).

c. Strategi dalam Pengukuhan Ekoproteksi

Strategi merupakan instrument yang digunakan untuk mencapai tujuan. Tujuan dari sebuah sistem ekoproteksi yang diperankan oleh empat pelindung pondok pesantren (Kyai-Ulama, Pendidik dan Pendidikan, Lembaga dan Pemerintah). Strategi tersebut antara lain:

1. Nilai dan Jiwa Kepondok Pesantrenan

Nilai-nilai dan jiwa kepondok pesantrenan adalah nilai yang didalamnya terdapat ajaranajaran yakni tujuan mencari ilmu di pesantren. Nilai-nilai pondok pesantren juga sebagai penguat motivasi kerja (Alhamuddin and Hamdani 2018).

2. Wakaf

Sebagai sebuah lembaga pendidikan islam, wakaf menjadi kunci awal berdirinya pondok pesantren. Dengan wakaf, seluruh keputusan yang menyangkut kehidupan pondok pesantrenakan ditentukan melalui musyawarah, bukan keputusan sepihak. Dengan begitu, semuanya akan berjalan dengan baik (Iwan Permana 2020).

3. Maksimalisasi Sumber Daya Lokal

Hal ini dapat diperankan oleh pendidik dan pendidikan yaitu dengan mengajarkan serta membekali santrinya dengan pendidikan agama islam (spiritualitas), manajemen, maupun bekal kewirausahaan. Sementara peran lembaga yaitu menfasilitasi (Solihin, Iwan Setiawan 2013).

4. Maksimalisasi Ekonomi Mandiri

Kemandirian mampu menjadikan pondok pesantren berdiri tanpa bergantung pada pihak manapun. Tujuan akhir dari manajemen ekonomi dan proteksi ekonomi adalah memaksimalkan model manajemen yang membuahkan hasil logis bagi kemandirian ekonomi pondok pesantren tersebut (S. N. Azizah 2016).

\section{Penutup}

Berdasarkan analisis pengelolaan ekonomi dan ekoproteksi di Pondok Pesantren yang telah dipaparkan secara keseluruhan, maka dapat disimpulkan bahwasanya secara keseluruhan kegiatan-kegiatan unit usaha ekonomi berbasis ekoprteksi di pondok pesantren menjadi penting adanya. Terlebih Mayoritas masyarkat Indonesia beragama Islam, serta posisi bangsa ini ialah menjadi bangsa yang tengah mengembangkan perekonomiannya ke kancah dunia sehingga menjadi suatu hal yang wajib untuk memiliki nilai-nilai kepondok pesantrenan yang kokoh, yang nantinya mampu menjadi basis perubahan sosial, kondisi sosial ekonomi yang masih dalam tahap berkembang tersebut. Dasar itu menjadi perlindungan yang kuat. Hal tersebut selaras dengan 3 pilar pengembangan unit usaha ekonomi, yaitu menciptakan iklim yang memungkinkan potensi masyarakat pesantren berkembang, memperkuat potensi yang dimiliki masyarakat pesantren dan melindungi unit usaha ekonominya.

Proses manajemen unit usaha ekonomi di Pondok Pesantren serta pengembangannya memiliki dampak yang sangat positif untuk mencapai kesejahteraan bersama. Dampak positif tersebut secara nyata dapat dilihat pada beberapa hal; a) terciptanya pola kader umat (santri dan masyarakat) yang mandiri dalam bidang ekonomi, b) terbentuknya pesantren yang mandiri dalam bidang ekonomi, c) menjadikan pesantren sebagai patner pemerintah, dan d) mampu mengangkat ekonomi umat (ekonomi masyarakat sekitar pesantren maupun masyarakat secara luas).

\section{Daftar Pustaka}

Alhamuddin, and Fahmi Fatwa Rosyadi Satria Hamdani. 2018. "Hidden Curriculum: Polarisasi Pesantren Dalam Upaya Membentuk Kesalehan Individu Dan Sosial (Case Study Pondok Modern Darussalam Gontor Ponorogo)." ALMURABBI: Jurnal Studi Kependidikan dan Keislaman 5(1): 50-65. http://ejournal.kopertais4.or.id/mata raman/index.php/murabbi/article/vie $w / 3351$. 
Anwarrosid, Muhammad Fatkhul. 2020. "Upaya Pengembangan Kewirausahaan Santri Melalui Unit Usaha Di Pondok Pesantren Wali Songo Ngabar Ponorogo."

Azizah, Fitria Nurul. 2017. 5 "Pembangunan Masyarakat Berbasis Pengembangan Ekonomi Pesantren Rubat Mbalong Ell Firdaus Tambaksari Kedungrejo Cilacap Jawa Tengah."

Azizah, Sit Nur. 2016. "Manajemen Unit Usaha Pesantren Berbasis Ekoproteksi (Studi Kasus Di Pondok Pesantren Al-Ihya Ulumuddin Kesugihan Cilacap)." AlTijary - Jurnal Ekonomi dan Bisnis Islam 2(1): 77-96.

Cholida, Diana, Sri Wahyuni, and Joko Widodo. 2020. "Strategi Transformasi Nilai Kewirausahaan Di Pondok Pesantren Mabadi'ul Ihsan Kabupaten Banyuwangi." JURNAL PENDIDIKAN EKONOMI: Jurnal IImiah IImu Pendidikan, IImu Ekonomi dan IImu Sosial 14(1): 201.

Faishal Achmad. 2012. "Bentuk-Bentuk Pengembangan Ekonomi Masyarakat Di Pesantren."

Fathoni, Muhammad Anwar, and Ade Nur Rohim. 2019. "Pesantren Value Added Sebagai Modal Pemberdayaan Ekonomi Masyarakat Kecamatan Cibadak Lebak Banten." Islamic Economics Journal 5(2): 221.

Gufronul, Abdullah. 2020. "Gaya Kepemimpinan Kiai Dalam Membangun Kemandirian Ekonomi Pesantren." Muhasabatuna 1(2): 3046.

Ishaq, M. 2018. "KH. Abdul Wahid Zaini Dan Pengembangan Pondok Pesantren Nurul Jadid Paiton Probolinggo."

Iwan Permana, Gina Sakinah. 2020. "Peran Wakaf Sebagai Islamic Social Finance Dalam Pemberdayaan Pondok Pesantren Tahfidz Al Maa Parung Bogor." Jurnal Ekonomi Syariah 5(2): 67-76.

http://jurnal.unsil.ac.id/index.php/jes /article/view/1991.

Januari, Anas Tania. 2018. "Model Pemberdayaan Ekonomi Pesantren (Studi Kasus Unit-Unit Usaha Di Pondok Modern Darussalam Gontor
Putri 5)."

Laksono, Bayu Adi, and Nasyikhatur Rohmah. 2019. "Pemberdayaan Masyarakat Melalui Lembaga Sosial Dan Pendidikan." Jurnal Pendidikan Nonformal 14(1): 1.

Lugina, Ugin. 2018. "Pengembangan Ekonomi Pondok Pesantren Di Jawa Barat." Risâlah, Jurnal Pendidikan dan Studi Islam 4(1, March): 53-64. http://jurnal.faiunwir.ac.id.

Marlina. 2014. "Potensi Pesantren Dalam Pengembangan Ekonomi Syariah." Hukum Islam 12(1): 117-34.

Marwini, Annisa Nur Salam. 2018. "Model Pengembangan Koperasi Pondok Pesantren (Kopontren) Berbasis EMoney Sebagai Upaya Akselerasi Ekonomi Syariah Di Indonesia." UNDIP 2(1).

Mughni, Dede Imam. 2018. "Strategi Pengembangan Kemandirian Ekonomi Santri (Studi Kasus Di Pondok Pesantren El-Bayan Bendasari Majenang Cilacap Jawa Tengah)."

Muhammad Anwar Fathoni, Ade Nur Rohim. 2019. "Peran Pesantren Dalam Pemberdayaan Ekonomi Umat Di Indonesia." Proceeding Conference on Islamic Management, Accounting, and Economics (CIMAE) 2: 133-40. https://journal.uii.ac.id/CIMAE/article /download/12766/9450.

Muhammad Khoirun Nasirin. 2020. 21 "Dakwah Ekonomi Umat Pada Pesantren Shiddiqiyyah."

Mukhidin. 2019. 53 FEBI UIN SULTAN MAULANA HASANUDDIN BANTEN "Peran Pemberdayaan Ekonomi Pada Lembaga Pendidikan Islam Di Kabupaten Pandeglang (Studi Dilakuka Pada PP Modern Dan Salafiyah)."

Musa. 2017. "Optimalisasi Peran Pemerintah Dalam Pemberdayaan Masyarakat: Sebuah Tawaran Dalam Mengentaskan Kemiskinan." Jurnal Dakwah dan Pengembangan Sosial Kemanusiaan 8(1): 107-25.

Muslimin. 2019. 53 Jurnal UIN Malang "Pengembangan Ekonomi Pesantren Melalui Gerakan Wirausaha."

Mustaghfiri, Muhammad Baqi. 2019. 
"Pemberdayaan Ekonomi Santri Melalui Agribisnis Di Pesantren Entrepreneur Al-Mawaddah Honggosoco Jekulo Kabupaten Kudus."

Muttaqin, Rizal. 2016. "Kemandirian Dan Pemberdayaan Ekonomi Berbasis Pesantren (Studi Atas Peran Pondok Pesantren Al-Ittifaq Kecamatan Rancabali Kabupaten Bandung Terhadap Kemandirian Eknomi Santri Dan Pemberdayaan Ekonomi Masyarakat Sekitarnya)." JESI (Jurnal Ekonomi Syariah Indonesia) 1(2): 65.

Nurholisoh, Nurholisoh. 2018. "Strategi Pengembangan Pondok Pesantren AlMu'awanah Dalam Meningkatkan Kreativitas Santri." Tadbir: Jurnal Manajemen Dakwah 3(2): 83-102.

Prayitno, Prima. 2016. "Pemberdayaan Sumber Daya Santri Melalui Entrepreneurshipo Di Pondok Pesantren Al-Ashriyyah Nurul Iman Islamic Boarding School Parung Bogor." Quality 4(2): 310-31.

Rahman, Kholilul. 2019. 1 FEBI UIN RADEN INTAN LAMPUNG "Analisis Peran Program Kemandirian Ekonomi Pesantren Bank Indonesia Dalam Mengembangkan Unit Usaha Pesantren (Studi Pada Pondok Pesantren Ushuluddin Lampung Selatan)."

http://www.ghbook.ir/index.php?nam

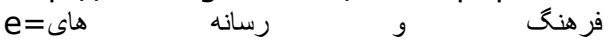
نوين\&option=com_dbook\&task=readon line\&book_id $=13650$ \&page $=73 \& \mathrm{chkh}$ ashk $=$ ED9C9491B4\&Itemid $=218 \&$ lan $\mathrm{g}=$ fa\&tmpl=component\%0Ahttp://w ww.albayan.ae\%0Ahttps://scholar.go ogle.co.id/scholar?hl=en\&q=APLIKAS I+PENGENA.

Renny, Oktafia, and Haryanto Budi. 2018. "Pengelolaan Keuangan Unit Usaha: Strategi Pengembangan Kapasitas Pondok Pesantren." al-Uqud: Journal of Islamic Economics 2(April): 14151.

Rimbawan, Y. 2012. "Pesantren Dan Ekonomi: Kajian Pemberdayaan Ekonomi Pesantren Darul Falah Bendo Mungal Krian Sidoarjo Jawa Timur." Aicis: 1180-99.

Sholihah Sari Rahayu, Aam Slamet Rusydiana, Mochamad AE Dunuraeni. 2020. "Meta Analysis of Pesantren's Economic
Research." International Journal of Nusantara Islam 8(1): 42-56. https://core.ac.uk/download/pdf/326 768118.pdf.

Solihin, Iwan Setiawan, Eliana Wulandari. 2013. "Kinerja Pusat Pelatihan Pertanian Perdesaan Swadaya Berbasis Pesantren Di Jawa Barat." MIMBAR AGRIBISNIS 53(9): 304-15.

Suharto, and Muhammad Iqbal Fasa. 2018. "Model Pengembangan Manajemen Bisnis Pondok Modern Darussalam Gontor Ponorogo, Indonesia." $\mathrm{Li}$ Falah: Jurnal Studi Ekonomi dan Bisnis Islam 3(2): 92-110.

Sulaiman, Adhi Iman, Masrukin Masrukin, Chusmeru Chusmeru, and Sri Pangestuti. 2016. "Pemberdayaan Koperasi Pondok Pesantren Sebagai Pendidikan Sosial Dan Ekonomi Santri." Jurnal Pendidikan dan Pemberdayaan Masyarakat 3(2): 109.

Sungkawaningrum, Fatmawati. 2013. "Peran Strategi Pesantren Dalam Peningkatan Kesejahteraan Ekonomi Masyarakat." FEBI 53(9): 16-28.

Supeno, Edy Imam. 2019. "Strategi Pemberdayaan Ekonomi Pesantren Dan Penguatan Daya Saing Industri Halal Dalam Upaya Pertumbuhan Ekonomi Indonesia." Jurnal Eksyar (Jurnal Ekonomi Syariah) 6(2): 1-19.

Yunita Nur Laili F.M., Irham Zaki. 2020. "Pemberdayaan Ekonomi Masyarakat Di Pondok Pesantren Dalwa Berdasarkan Model Evaluasi Sumatif CIPP." Jurnal Ekonomi Syariah Teori dan Terapan 5(1): 55.

Zaenudin, Akbar. 2018. "Model Manajemen Unit Bisnis Pesantren." Jurnal Pengembangan Wiraswasta 20(1): 11. 